\begin{tabular}{|c|c|}
\hline \multicolumn{2}{|c|}{$\begin{aligned} \text { 日本一タイ・フィリピン } & \text { 国際共同研究「交通」 } \\
\text { 平成 } 30 \text { 年度 } & \text { 年次報告書 }\end{aligned}$} \\
\hline 研究課題名（和文） & IITSL : スマートライフを実現する知的統合交通 \\
\hline 研究課題名（英文） & Intelligent Integrated Transport for Smart Life \\
\hline 日本側研究代表者氏名 & 土井健司 \\
\hline 所属・役職 & 大阪大学・教授 \\
\hline 研究期間 & 平成 28 年 6 月 24 日 〜令和 2 年 3 月 31 日 \\
\hline
\end{tabular}

1. 日本側の研究実施体制

\begin{tabular}{|c|c|c|}
\hline 氏名 & 所属機関 · 部局 - 役職 & 役割 \\
\hline 土井健司 & $\begin{array}{l}\text { 大阪大学・大学院工学研究科・教 } \\
\text { 授 }\end{array}$ & $\begin{array}{l}\text { IITSL の概念枠組み（Conceptual } \\
\text { Framework）の設計 }\end{array}$ \\
\hline 猪井博登 & $\begin{array}{l}\text { 富山大学·都市デザイン学部・准 } \\
\text { 教授 }\end{array}$ & $\begin{array}{l}\text { IITSL の調査・分析枠組み（Research } \\
\text { and Analytical Framework）の検討 }\end{array}$ \\
\hline 林 良嗣 & $\begin{array}{l}\text { 中部大学・総合工学研究所国際 } \\
\text { センター中部高等学術研究所・ } \\
\text { 教授 }\end{array}$ & $\begin{array}{l}\text { タイ・バンコクおよびフィリピン・メ } \\
\text { トロマ二ラの実情に応じたリープフロ } \\
\text { ッグ戦略の立案 }\end{array}$ \\
\hline 杉山 郁夫 & $\begin{array}{l}\text { 神戸情報大学院大学・情報技術 } \\
\text { 研究科・特任教授 }\end{array}$ & $\begin{array}{l}\text { CPS に立脚し政策決定および合意形成 } \\
\text { を促すための可視化手法の開発 }\end{array}$ \\
\hline 横山 輝明 & $\begin{array}{l}\text { 国立研究法人 情報通信研究機 } \\
\text { 構・研究員 }\end{array}$ & $\begin{array}{l}\text { センシング技術に基づく交通行動のモ } \\
\text { ニタリング方法の開発 }\end{array}$ \\
\hline 紀伊 雅敦 & 香川大学・創造工学部 · 教授 & $\begin{array}{l}\text { 俯瞰的情報基盤の構築と都市空間デー } \\
\text { タの可視化 }\end{array}$ \\
\hline 中村 一樹 & 名城大学・工学部 - 准教授 & $\begin{array}{l}\text { 移動に関わる空間の質と総合的な生活 } \\
\text { の質の評価方法の開発 }\end{array}$ \\
\hline 有村 幹治 & $\begin{array}{l}\text { 室蘭工業大学·工学研究科・准教 } \\
\text { 授 }\end{array}$ & $\begin{array}{l}\text { 人の活動・移動に関する空間相関解析 } \\
\text { と IoH 型交通行動調査の方法論の開発 }\end{array}$ \\
\hline
\end{tabular}




\section{2. 日本側研究チームの研究目標及び計画概要}

サイバー・フィジカル・システム（CPS）を支える技術パーソナル情報保護に関わるガイド ラインを構築するため、我が国における制度的制約および実施方法に関する知見の収集を行 う。また、Wifi パケットセンサーや画像認識を用いた人流計測においては、プーケットで実 地検証を行い、精度の確認を目指す。

さらに、VR を用いた地域住民、市民との Walkable な co-design 技術の確立を目指し、 移動空間の物理的環境、心理的な環境を含めた LEEDs の指標を元にした移動空間を含む街 区の質的評価を行う。

\section{3. 日本側研究チームの実施概要}

Intelligent Integrated Transport for Smart Life を実現するため必要な CPS を支える 技術の開発、分析方法の開発を行った。本研究で用いた技術はWifi パケットセンサー、位 置情報を収集するスマホアプリ、画像認識を用いた人流計測、マイクロシミュレーションに よる交通行動の分析フレームワーク、モバイル空間統計などである。人々のミクロな動き を実測する方法、データのクリーニングに関する技術、得られたデータから巨視的な人の 動きを検証する分析方法の開発、その精度の検証を行った。これらの技術を日本（岐阜市 柳ヶ瀬、神戸市水道筋、香川県、北海道室蘭市) でケーススタディ地域を設定し、試験的 に計測を行った。

これらの結果から、人々の中心市街地で回遊する行動を把握し、回遊先や滞留時間が分 析でき、まちなかの活性化事業などを評価する枠組みを構築することができた。画像認識 を用いた人流計測では、商店街における来訪客を撮影した画像を分析し、性別、年齢など の分析精度を明らかにした。その結果、計画等で用いるには十分な精度があることを示せ た。マイクロシミュレーションによる交通行動の分析フレームワークでは人の行動などを マイクロシミュレーションにより再現し、交通事業の評価を行える体制を構築することが できた。モバイル空間統計と人口などのメッシュ統計を統合することにより、起点

(Origin) から終点 (Destination) の把握（OD 把握）などを行うことができる結果を 得、人の行動を分析する体制が構築された。

上記のように、人の行動を把握することができる技術の開発が進んだ状況である。これ に加えて、本研究で得られた Walkability などをもとに、情報を提供する MaaS (Mobility as a Service) アプリを開発し、タイのプーケットで試験提供を行った。この際行った利用 者調査では、提供した情報により、人の交通行動を変化させることができたことが分かつ た。 